\title{
Editorial: Usage of Social Neuroscience in E-Commerce Research - Current Research and Future Opportunities
}

\author{
Mirjana Pejić Bach \\ University of Zagreb, Faculty of Economics \& Business, Department of Informatics, Zagreb, Croatia, \\ Co-Editor \\ mpejic@efzg.hr \\ January 2018
}

\section{Introduction}

Electronic commerce (e-commerce) has become one of the main drivers of the digital transformation of both national and global economies. E-commerce was defined as a process including both the sell-buy relationships and transactions among companies and individuals, and "the corporate processes that support the commerce within individual firms" [17]. E-commerce, also known as e-business, has become a widespread term in the late 90's, while it has been present for much longer period of time, from 80's [16]. Two main types of e-commerce are defined, based on the types of clients: business-to-business (B2B) and business-to-customers (B2C). However, the emergence of social media and peer-to-peer networks enticed the additional type of e-commerce: customers-to-customers (C2C), in which transactions are exchanged not only for money, but also in exchange for personal services or other goods. In addition, due to the prevalent usage of smart-phones, e-commerce has become often referred to as $\mathrm{m}$-commerce [2].

Research area of e-commerce is composed by many scientific disciplines, such as computer science, psychology, economics, and natural sciences, and applied areas, such as marketing, management, finance and engineering [5]. Therefore, e-commerce is a constituent part of the social sciences, which are defined by Merriam Webster Dictionary as a branch of science that deals with the institutions and functioning of human society and with the interpersonal relationships of individuals as members of society. Social sciences, like other sciences, are using scientific methods, which are used in order to develop scientific knowledge using a three phase approach: (i) make plausible observations; (ii) interpret these observations in objective manner, and (iii) generalize the interpretations into scientific knowledge. Social sciences use two major groups of methods to investigate human society and individual as members of society: quantitative (e.g. data collected through survey reports), and qualitative (e.g. data collected using interviews or organizational narratives). Scientific methods are required to have the following characteristics: replicability, precision, falsifiability, and parsimony [1]. However, quantitative and qualitative methods traditionally used in social sciences are prone to be vulnerable to different threats to their validity, e.g. sample bias.

Social neuroscience is a method that is using different data generated as the result of the human physiology, in order to "understand the associations and influences between social and biological levels of organization" [4]. NeurolS has emerged as a new branch of applied social neuroscience, with the goal to use neurophysiological tools for gathering presumably objective data directly from the human body for the purpose of information systems research [7]. Two groups of neurophysiological tools are used: (i) psycho physiological tools, such as skin conductance response and eye tracking, and brain imaging tools, such as functional magnetic resonance imaging and electroencephalography, which are often used in combination with the traditional behavioural data sources used in social research. These tools allow the quantification of human reactions to different aspects of information systems, which are the essential part of e-commerce.

In this paper, we investigate to what extent the social neuroscience has been utilized in e-commerce research. We use the systematic approach, searching Scopus database in order to identify the papers in the area of e-commerce that are using neurophysiological tools. Bibliometric analysis has been done, according to type of publication, affiliations, journals and conferences, authors' countries, and scientific disciplines covered (due to the interdisciplinarity of e-commerce research). Papers are analyzed according to the type of neurophysiological tools used, with the goal to trace the most often used tools, and the topics researched with their utilization. Gaps in the current research are identified in order to provide guidance for future research directions.

The paper is organized as follows. After the introduction, the second section provides a specification of used methodology. In the third section the systematic bibliometric analysis is provided. The usage of neurophysiological tools in identified e-commerce research papers is outlined in the fourth section, with the brief description of their usage and examples of research. The final section provides an overview of research gaps and road to future research. 


\section{Methodology}

In the first phase, Scopus database has been searched in order to track papers that describe the usage of neurophysiological tools for the purpose of researching e-commerce topics, e.g. usage of eye tracking for the investigation of the users' habits of searching items on the online shop website [8].

Table 1 outlines the research strategy, that included all types of papers (conference papers, peer-review journal papers, book chapters) indexed in Scopus database in the period from 1997 to 2017.

In the first phase, we searched Scopus in order to detect the papers that have words e-commerce, electronic commerce or m-commerce in the title, abstract or keywords of the paper, which resulted with the 60.241 papers. In the second phase, these papers were refined using the words related to the neuroscience or neurosis or the names of different neuropsychological tools, which results with 155 papers. Finally, in the third phase, these papers were refined by reading the abstracts of the papers in order to detect those that present the specific usage of neurophysiological tools in a specific area of e-commerce, which resulted in 89 papers that are the focus of this research. These papers are be examined in this review in order to provide conclusion to what extent the neuropsychological tools are used as methodological tools in e-commerce research papers. The list of identified papers is available on request from the author.

Table 1: Research strategy for finding papers that describe the usage of neurophysiological tools in a specific area of e-commerce

\begin{tabular}{|l|l|l|}
\hline \multicolumn{2}{|l|}{ Research strategy } & $\begin{array}{l}\text { Number of } \\
\text { papers }\end{array}$ \\
\hline Scopus database (1997-2017) & 60.241 papers \\
\hline Phase I & $\begin{array}{l}\text { TITLE-ABS-KEY e-commerce OR electronic } \\
\text { commerce OR m-commerce }\end{array}$ & 155 papers \\
\hline Phase II & $\begin{array}{l}\text { Refined by: TOPIC: (neuroscience OR neurois OR eye } \\
\text { tracking OR skin conductance response OR SCR OR } \\
\text { facial electromyography OR Femg OR } \\
\text { electrocardiogram OR EKG OR functional magnetic } \\
\text { resonance OR fMRI OR positron emission tomography } \\
\text { OR PET OR magnetoecephalography OR MEG OR } \\
\text { electroencephalography OR EEG) }\end{array}$ & 89 papers \\
\hline Manual extraction & \multicolumn{2}{|l|}{} \\
\hline Phase III & $\begin{array}{l}\text { Reading of abstracts with the goal to trace research } \\
\text { papers that describe the usage of neurophysiological } \\
\text { tools in a specific area of e-commerce. }\end{array}$ & \\
\hline
\end{tabular}

\section{Bibliometric Analysis}

Table 2 presents the number of papers according to publication years, source publication, and research area of papers.

Although the Scopus database was searched during the period from 1997 to 2017, the first paper that describe the usage of neuropsychological tools in the area of e-commerce research are detected in 2003 (two papers). In the next two years (2004-2005) there was no publications describing the usage of neuropsychological tools in the area of ecommerce research, while the number of these papers stagnated in the period 2006-2009. The number of publications increased in 2010 to 6 and in 2011 to 7 publications, and after 2012 more than 10 publications per year are published that investigate the usage of neuropsychological tools in the area of e-commerce research. It can be concluded that the number of publications in this area is increasing, but not yet at the fast growing rate.

In order to investigate the multidisciplinary of the papers, they were also analysed according to the research area assigned to papers as part of the Scopus indexation process. Most of the papers were classified as Computer Science papers. Following areas are represented with more than 10 papers are: Business, Management and Accounting (20 papers), Mathematics (16 papers), Decision Sciences (13 papers), and Social Sciences (12 papers). Other areas are represented with substantially lower number of papers. These findings indicate that papers that develop their research findings in the area of e-commerce with the usage of neuropsychological tools are mainly focused to Computer 
Science, but are also tackling number of other research areas. Appendix A provides the list of 10 most cited papers indicating their research area.

Among 89 papers, $65 \%$ were published in conference proceedings, $34 \%$ in peer-reviewed journals, and 1 as a book chapter. Most of the papers are published in the Springer conference series: Lecture Notes in Computer Science Including Subseries Lecture Notes in Artificial Intelligence and Lecture Notes in Bioinformatics (14 papers), and ACM International Conference Proceeding Series (8 papers). Large number of publications (67 journals, book chapters and conference proceedings) published only one paper focusing to the usage of neuropsychological tools in the area of ecommerce research. Based on this findings, we conclude that the journal that would specialize in this area is not yet profiled, which is an interesting opportunity that would support the development of this type of research.

Table 2: Publication years, publication source and research areas

\begin{tabular}{|c|c|c|c|c|c|}
\hline Year & $\begin{array}{l}\text { \# of } \\
\text { papers }\end{array}$ & Research area & \# of papers & Source & $\begin{array}{l}\text { \# of } \\
\text { papers }\end{array}$ \\
\hline 2017 & 13 & Computer Science & 70 & $\begin{array}{l}\text { Lecture Notes in Computer } \\
\text { Science Including Subseries } \\
\text { Lecture Notes in Artificial } \\
\text { Intelligence and Lecture } \\
\text { Notes in Bioinformatics* }\end{array}$ & 14 \\
\hline 2016 & 12 & $\begin{array}{l}\text { Business, Management } \\
\text { and Accounting }\end{array}$ & 20 & $\begin{array}{l}\text { ACM International } \\
\text { Conference Proceeding } \\
\text { Series }\end{array}$ & 8 \\
\hline 2015 & 12 & Mathematics & 16 & Others & 67 \\
\hline 2014 & 14 & Decision Sciences & 13 & & \\
\hline 2013 & 11 & Social Sciences & 12 & & \\
\hline 2012 & 11 & Engineering & 8 & & \\
\hline 2011 & 7 & Arts and Humanities & 5 & & \\
\hline 2010 & 6 & Psychology & 5 & & \\
\hline 2009 & 3 & $\begin{array}{l}\text { Economics, } \\
\text { Econometrics and } \\
\text { Finance }\end{array}$ & 2 & & \\
\hline 2008 & 1 & $\begin{array}{l}\text { Biochemistry, Genetics } \\
\text { and Molecular Biology } \\
\text { \& Chemistry }\end{array}$ & 2 & & \\
\hline 2007 & 1 & Energy & 1 & & \\
\hline 2006 & 1 & Environmental Science & 1 & & \\
\hline 2003 & 2 & Materials Science & 1 & & \\
\hline
\end{tabular}

Source: Authors' work

Note: * Lecture Notes include various conferences under one publication label.

Table 3 presents the most frequent authors, authors' affiliations and authors' country which yielded two or more papers.

Only one researcher authored five papers (Lee, K.C.), while six researchers authored three papers (Auinger, A., Chae, S.W., Pu, P., Sivaji, A., Wang, Q., and Yang, S.F.). Large number of researchers authored two papers (21 researcher), which leads to the conclusion that the most represented authors investigate the field of e-commerce with the usage of neurophysiological tools mostly sporadically, and that it is rarely the main focus of the research of a particular author.

Table 3 also presents the distribution of papers by authors' affiliations and authors' countries. The Republic of China, United States, South Korea, United Kingdom, Canada and Hong Kong, were the top seven countries publishing ecommerce papers using neurophysiological tools. Countries with four publications are: Taiwan, Germany, and India, while the countries with three publications are: Japan, Malaysia, Singapore, and Thailand.

The distribution of publications according the authors' affiliations reveal that the top three institutions are: Sungkyunkwan University, Zhejiang University, and Ecole Polytechnique Federale de Lausanne. Institutions with three publications are: National Sun Yat-Sen University Taiwan, National University of Singapore, UCL, Chulalongkorn University, and McMaster University. 
Table 3: The most frequent authors, authors' affiliations and authors' country $(\geq 2)$

\begin{tabular}{|c|c|c|c|c|c|}
\hline Authors & \# of papers & Authors' affiliations & $\begin{array}{l}\# \text { of } \\
\text { authors }\end{array}$ & Authors' countries & $\begin{array}{l}\text { \# of } \\
\text { authors }\end{array}$ \\
\hline Lee, K.C. & 5 & Sungkyunkwan University & 5 & $\begin{array}{l}\text { The Republic of } \\
\text { China }\end{array}$ & 16 \\
\hline Auinger, A. & 3 & Zhejiang University & 4 & United States & 9 \\
\hline Chae, S.W. & 3 & $\begin{array}{l}\text { Ecole Polytechnique Federale } \\
\text { de Lausanne }\end{array}$ & 4 & South Korea & 7 \\
\hline $\mathrm{Pu}, \mathrm{P}$. & 3 & $\begin{array}{l}\text { National Sun Yat-Sen } \\
\text { University Taiwan }\end{array}$ & 3 & United Kingdom & 7 \\
\hline Sivaji, A. & 3 & $\begin{array}{l}\text { National University of } \\
\text { Singapore }\end{array}$ & 3 & Canada & 6 \\
\hline Wang, Q. & 3 & $\mathrm{UCL}$ & 3 & Hong Kong & 6 \\
\hline Yang, S.F. & 3 & Chulalongkorn University & 3 & Switzerland & 6 \\
\hline Castagnos, S. & 2 & McMaster University & 3 & Austria & 5 \\
\hline Chen, L. & 2 & $\begin{array}{l}\text { National Information Society } \\
\text { Agency }\end{array}$ & 2 & Taiwan & 4 \\
\hline Courtemanche, $\mathrm{F}$. & 2 & NIPA & 2 & Germany & 4 \\
\hline Cyr, D. & 2 & Fachhochshule Oberosterreich & 2 & India & 4 \\
\hline Dufresne, $A$. & 2 & Universiti Teknologi Petronas & 2 & Japan & 3 \\
\hline Head, M. & 2 & University of Zilina & 2 & Malaysia & 3 \\
\hline Holzinger, A. & 2 & $\begin{array}{l}\text { Hong Kong University of } \\
\text { Science and Technology }\end{array}$ & 2 & Singapore & 3 \\
\hline Hsieh, A.Y. & 2 & Universite de Montreal & 2 & Thailand & 3 \\
\hline Jankowski, J. & 2 & $\begin{array}{l}\text { Chinese Culture University } \\
\text { Taiwan }\end{array}$ & 2 & Norway & 2 \\
\hline Lo, S.K. & 2 & Beihang University & 2 & Poland & 2 \\
\hline $\mathrm{Ma}, \mathrm{Q}$ & 2 & Hong Kong Baptist University & 2 & Slovakia & 2 \\
\hline Rattanawicha, $\mathrm{P}$. & 2 & Simon Fraser University & 2 & & \\
\hline Riedl, R. & 2 & $\begin{array}{l}\text { Johannes Kepler Universitat } \\
\text { Linz }\end{array}$ & 2 & & \\
\hline Riegelsberger, J. & 2 & Universitat Basel & 2 & & \\
\hline Sasse, M.A. & 2 & Northeastern University China & 2 & & \\
\hline Seo, Y.W. & 2 & Bentley University & 2 & & \\
\hline Soo, S.T. & 2 & $\begin{array}{l}\text { West Pomeranian University of } \\
\text { Technology }\end{array}$ & 2 & & \\
\hline Teo, H.H. & 2 & & & & \\
\hline Watróbski, J. & 2 & & & & \\
\hline Zhang, Z. & 2 & & & & \\
\hline Ziemba, P. & 2 & & & & \\
\hline
\end{tabular}

\section{Usage of Neurophysiological Tools in E-Commerce}

Two major groups of neurophysiological tools are used in neurols research [7]: (i) psychophysiological tools (eye tracking, skin conductance response, facial electromyography, and electrocardiogram), and (ii) brain imaging tools (functional magnetic resonance imaging, positron emission tomography, electroencephalography, and magnetoencephalography).

Psychophysiological tools track the respondent's actions and thoughts based on the respondent eye activity (eye pupil location (gaze) and movement measured by eye tracking), skin activity (sweat in eccrine glands of the palms or feet measured by skin conductance response), face activity (electrical impulses caused by muscle fibres, measured by facial electromyography), or heart activity (electrical activity of the heart on the skin measured by EEG). Brain imaging tools aim at tracking the respondent's actions and thoughts reflected in the brain, by measuring the different manifestations of brain activity, e.g. functional magnetic resonance imaging is measuring the neural activity by changes in blood flow.

Identified 89 e-commerce papers that describe the usage of neurophysiological tools were classified according to the tools used. Table 4 presents the number of papers among identified 89 e-commerce papers according to the usage of neurophysiological tools. Research revealed that the largest number of papers described the usage of eye tracking (78 papers; $87.6 \%$ ), followed by the electrocardiogram (8 papers; $9 \%$ ). Other tools usage is described only in few papers (skin conductance response - 2 papers, functional magnetic resonance imaging - 3 papers). Four tools are not described to be used in e-commerce research (facial electromyography, electrocardiogram, positron emission tomography, and magnetoencephalography). 
Table 4: Usage of neurophysiological tools in e-commerce papers ( $n=89$ papers)

\begin{tabular}{|l|l|l|l|}
\hline Neurophysiological Tools & Focus of Measurement & $\begin{array}{l}\text { \# of } \\
\text { papers }\end{array}$ & $\begin{array}{l}\% \\
(\mathrm{n}=89)\end{array}$ \\
\hline Psychophysiological Tools & \multicolumn{2}{|l|}{} \\
\hline Eye Tracking & Eye pupil location (gaze) and movement & $78^{*}$ & $87.6 \%$ \\
\hline Skin Conductance Response (SCR) & $\begin{array}{l}\text { Sweat in eccrine glands of the palms or } \\
\text { feet }\end{array}$ & $2^{*}$ & $2.2 \%$ \\
\hline Facial Electromyography (fEMG) & $\begin{array}{l}\text { Electrical impulses caused by muscle } \\
\text { fibres }\end{array}$ & 0 & 0 \\
\hline Electrocardiogram (EKG) & Electrical activity of the heart on the skin & 0 & 0 \\
\hline Brain Imaging Tools & \multicolumn{2}{|l|}{} \\
\hline $\begin{array}{l}\text { Functional Magnetic Resonance Imaging } \\
\text { (fMRI) }\end{array}$ & Neural activity by changes in blood flow & 3 & $3.4 \%$ \\
\hline Positron Emission Tomography (PET) & Metabolic activity by radioactive isotopes & 0 & 0 \\
\hline Electroencephalography (EEG) & Electrical brain activity on the scalp & 8 & $9.0 \%$ \\
\hline Magnetoencephalography (MEG) & $\begin{array}{l}\text { Changes in magnetic fields by brain } \\
\text { activity }\end{array}$ & 0 \\
\hline
\end{tabular}

Source: Authors' work, based on Dimoka et al. (2012).

Note: *One paper is using both eye-tracking and skin conductance response analysis

\section{Psychophysiological Tools in E-Commerce Research}

In this part of the paper the utilization of the most used psychophysiological tools in e-commerce research is presented: eye tracking, and skin conductance response.

\section{Eye Tracking}

Papers investigating e-commerce in most of the cases used eye tracking. These tools measure the eyes position (where the respondent is looking) and eyes movement (the eye's movement in relation to the head), and collected data track the length of focus of respondent's eyes on certain place on the image (e.g. computer or mobile phone screen) or stimulus [6], [14]. The reading of the papers revealed that there are 78 papers that use eye tracking as a methodology for researching e-commerce. Detailed analysis of the research papers is not the goal of this editorial. However, in order to investigate what are the topics of the e-commerce papers that use eye tracking tools for researching to topic of interest, we used the phrase extraction process combined with the cluster analysis conducted by Wordstat Provalis software. Table 5 presents phrases with more than 2 words with the frequency of occurrence $\geq$ 5 , and figure 1 presents the results of the cluster analysis that identified 7 groups of topics in e-commerce, using Jaccard's coefficients, that are analysed with the eye tracking: (i) visual attention of human brands; (ii) image appeal of human images; (iii) decision quality generated by the usage of recommender systems; (iv) product image used in human-computer interactions measured by the fixation count and fixation duration; (v) purchase intentions measured by the high and low elaborations as well as peripheral cues; (vi) impacts of banner ads on brand awareness and (vi) viewing behaviour in relation to user experience. Examples of research related to the topics are the following as provided in respective order [9], [10], [11], [12], [13], [18].
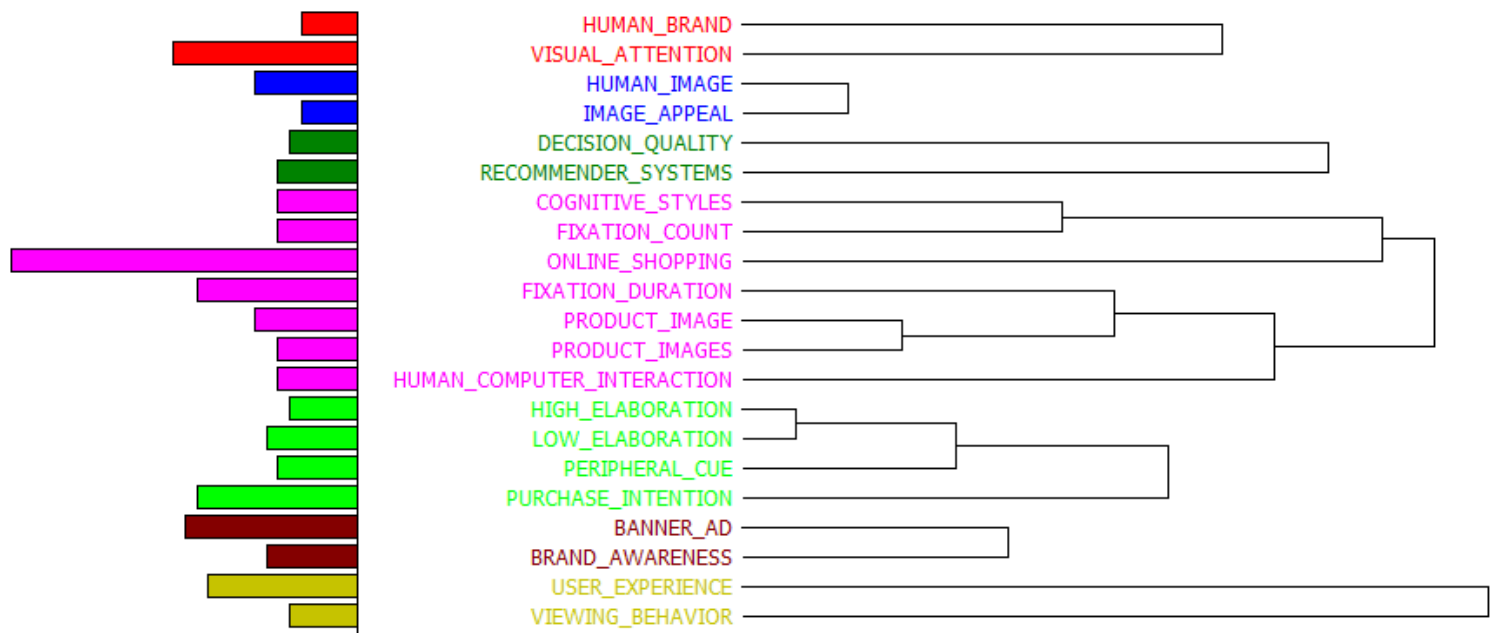

Figure 1: Cluster analysis of phrases in abstracts of papers using eye tracking for the investigation of e-commerce topics of research 
Table 5: Phrases of e-commerce papers using eye tracking ( $\geq 5$ occurrences)

\begin{tabular}{|c|c|c|c|}
\hline & $\begin{array}{l}\text { \# of } \\
\text { occurences }\end{array}$ & $\begin{array}{l}\text { \# of } \\
\text { papers }\end{array}$ & $\begin{array}{l}\% \text { of } \\
\text { papers }\end{array}$ \\
\hline Online shopping & 35 & 21 & $26.92 \%$ \\
\hline Visual attention & 16 & 9 & $11.54 \%$ \\
\hline Banner ad & 15 & 2 & $2.56 \%$ \\
\hline Fixation duration & 14 & 8 & $10.26 \%$ \\
\hline Purchase intention & 14 & 6 & $7.69 \%$ \\
\hline User experience & 13 & 10 & $12.82 \%$ \\
\hline Image appeal & 10 & 3 & $3.85 \%$ \\
\hline Human brand & 10 & 2 & $2.56 \%$ \\
\hline Product image & 9 & 3 & $3.85 \%$ \\
\hline Human image & 9 & 2 & $2.56 \%$ \\
\hline Historical sales & 9 & 1 & $1.28 \%$ \\
\hline Low elaboration & 8 & 2 & $2.56 \%$ \\
\hline Brand awareness & 8 & 2 & $2.56 \%$ \\
\hline Human computer interaction & 7 & 5 & $6.41 \%$ \\
\hline Fixation count & 7 & 5 & $6.41 \%$ \\
\hline Recommender systems & 7 & 4 & $5.13 \%$ \\
\hline Cognitive styles & 7 & 3 & $3.85 \%$ \\
\hline Product images & 7 & 2 & $2.56 \%$ \\
\hline Attentional resources & 7 & 1 & $1.28 \%$ \\
\hline Peripheral cue & 7 & 1 & $1.28 \%$ \\
\hline Decision quality & 6 & 2 & $2.56 \%$ \\
\hline High elaboration & 6 & 2 & $2.56 \%$ \\
\hline Viewing behavior & 6 & 2 & $2.56 \%$ \\
\hline Usability evaluation & 5 & 4 & $5.13 \%$ \\
\hline Website design & 5 & 4 & $5.13 \%$ \\
\hline Trust building & 5 & 2 & $2.56 \%$ \\
\hline Banner ad fixation & 5 & 1 & $1.28 \%$ \\
\hline Brand image appeal & 5 & 1 & $1.28 \%$ \\
\hline Banner ad position & 5 & 1 & $1.28 \%$ \\
\hline Human preference & 5 & 1 & $1.28 \%$ \\
\hline Product knowledge & 5 & 1 & $1.28 \%$ \\
\hline Product pictures & 5 & 1 & $1.28 \%$ \\
\hline
\end{tabular}

Source: Authors' work, using Provalis Wordstat software

Figure 2 presents the proximity plot indicating which phrases occur the most often with the phrase online shopping, which is the most frequent phrase. The phrases that occur are related to the eye movement, such as visual attention, fixation count and duration, high and low elaboration and viewing behaviour. However, other phrases that occur indicate the particular topics of the research, such as purchase intention, brand awareness, decision quality, human brands and images, image appeal, product images, website design and user experience.

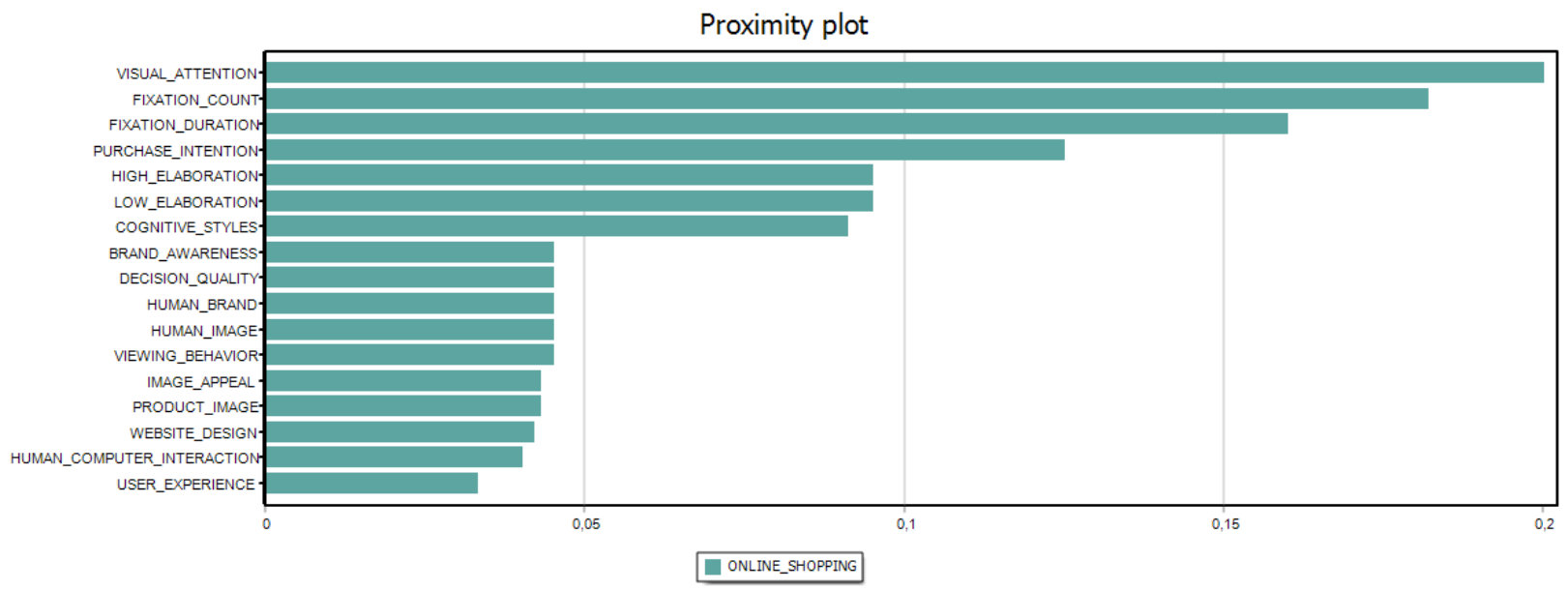

Figure 2: Proximity plot of the phrase occurring the most often with the phrase online shopping 


\section{Skin Conductance Response}

Only two papers used the skin conductance response, and one of them in combination with eye tracking. Example of the research using skin conductance in e-commerce is its usage 'as proxies for the immediate emotions and overall arousal of human bidders in a lab experiment with human and computerized counterparts' [15].

\section{Brain imaging Tools in E-Commerce Research}

In this part of the paper the utilization of the most used brain imaging tools in e-commerce research is presented: functional magnetic resonance imaging and electroencephalography.

\section{Functional Magnetic Resonance Imaging (fMRI)}

When neural activity occurs in a brain, it generates a stronger change in blood flow than in oxygen metabolism, which causes the blood to be more oxygenated in case of increased neural activity. This effect is called blood oxygenation level dependent (BOLD) effect, and is used as a basis for $\mathrm{fMRI}$, which has excellent spatial resolution, which precisely measures the location of the event in the brain, while the temporal resolution is weak, due to the length of the BOLD effect. Example of the research using $\mathrm{FMRI}$ is capturing consumer's neural activities in the region of interest (ROI) related to metacognition across the conditions of e-commerce websites in a manipulated online shopping scenario [19].

\section{Electroencephalography (EEG)}

EEG quantifies the 'electrical brain activity from extracellular ionic currents that are caused by dendritic activity' [8]. It has excellent temporal resolution measured in milliseconds, but spatial resolution is poor. Example of the usage of EEG in e-commerce research is the measurement of the response of participants to social commerce and e-commerce reviews, where social commerce reviews were from friends, and e-commerce reviews from strangers. By the usage of $E E G$, it was revealed that participants paid more consideration to the social commerce reviews compared to ecommerce reviews [3].

\section{Conclusion}

Neurophysiological tools have attracted significant attention in diverse areas of social science research. Its usage in the area of information systems has become widespread, and broader description of the neurophysiological tools with the information of their pricing is provided by Dimoka et al. [7]. The goal of this editorial is to incite the readers of Journal of Theoretical and Applied Electronic Commerce Research to consider the usage of neurophysiological tools in their research. With this goal in mind, the systematic search of Scopus database was conducted in order to detect the papers that report the usage of neurophysiological tools as a methodological tool for researching topics related to e-commerce. Bibliographical analysis revealed that the publication of studies reporting the usage of neurophysiological tools in e-commerce research is increasing, but it is dispersed across various journals and conference proceedings. Analysis revealed 89 papers that use in most of the cases eye-tracking methodology to investigate different topics, such as appeal of human images and impacts of banner ads on brand awareness. Other neurophysiological tools were used to much lower extent. Possible reason of the popularity of eye tracking is due to its price affordability and measurement of eye activity, which is tightly related to e-commerce that is conducted over web and mobile sites.

This overview of the usage of neurophysiological tools in e-commerce research leaves number of questions unanswered. Only a few of them will be mentioned here. What are the benefits of neurophysiological tools usage for the purpose of e-commerce research, in combination and, in comparison with behavioural research, such as survey self-reporting studies and web mining behavioural data, taking into account effort and price of the research? What are the possible pitfalls in conducting the e-commerce research using neurophysiological tools, and how to avoid them? Which topics of e-commerce are already investigated with high-quality research using neurophysiological tools, and which topics are emerging as important?

\section{References}

[1] A. Bhattacherjee. (2012) Social science research: Principles, methods, and practices. Scholar Commons. [Online]. Available: http://scholarcommons.usf.edu/oa textbooks/3

[2] S. Balasubramanian, R.A. Peterson and S.L. Jarvenpaa, Exploring the implications of m-commerce or markets and marketing, Journal of the Academy of Marketing Science, vol. 30, no. 4, pp. 348, 2002.

[3] Y. Bai, Z. Yao, F. Cong, and L. Zhang, Event-related potentials elicited by social commerce and electroniccommerce reviews, Cognitive Neurodynamics, vol. 9, no. 6, pp. 639-648, 2015. 
[4] J.T. Cacioppo, G.G. Berntson and J. Decety, Social neuroscience and its relationship to social psychology, Social Cognition, vol. 28, no. 6, pp. 675-685, 2010.

[5] N. Cerpa, Welcome, Journal of Theoretical and Applied Electronic Commerce Research (JTAER), vol. 1, no. 1, pp. $1,1996$.

[6] D. Cyr, M. Head, H. Larios, and B. Pan. Exploring human images in website design: A multi-method approach, MIS Quarterly, vol. 33, no. 3, pp. 539-566, 2009.

[7] A. Dimoka, R. Banker, D. Rajiv, I. Benbasat, F.D. Davis, A.R. Dennis, D. Gefen, A. David, A. Gupta, A. Ischebeck, P. Kenning, P.A. Pavlou, G. Müller-Putz, R. Riedl, J. vom Brocke, and Jan B. Weber, On the use of neurophysiological tools in IS research: Developing a research agenda for neurolS, MIS Quarterly, vol. 36, no. 3, pp. 679-702, 2010.

[8] A. Hernandez and M.L. Resnick, Placement of call to action buttons for higher website conversion and acquisition: An eye tracking study, Proceedings of the Human Factors and Ergonomics Society, vol. 57, no. 1, pp. 1042-1046, 2013.

[9] Y.M. Hwang and K.C. Lee, How do consumers' cognitive styles affect their visual attention patterns? - Emphasis on field-independent and field- dependent styles, International Journal of Multimedia and Ubiquitous Engineering, vol. 10, no. 11, pp. 123-132, 2015

[10] H. Lin, S. Yang, An eye movement study of attribute framing in online shopping, Journal of Marketing Analytics, vol. 2, no. 2, pp. 72-80, 2015.

[11] M. Resnick and W. Albert, The impact of advertising location and user task on the emergence of banner ad blindness: An eye -tracking study, International Journal of Human-Computer Interaction, vol. 30, no. 3, pp. 206219, 2014.

[12] J.N. Sari, R. Ferdiana, P.I. Santosa, and L.E. Nugroho, An eye tracking study: Exploration customer behavior on web design, in Proceedings of the International $\mathrm{HCl}$ and UX Conference in Indonesia, ACM International Conference Proceeding Series, Indonesia, pp. 69-72, 2015.

[13] Y.W. Seo, S.W. Chae and K.C. Lee. The impact of human brand image appeal on visual attention and purchase intentions at an e-commerce website, in Proceedings Asian Conference on Intelligent Information and Database Systems, Kaohsiung, Taiwan, pp.1-9, 2012.

[14] S. Shimojo, C. Simion, E. Shimojo, and C. Scheier, Gaze bias both reflects and influences preference, Nature Neuroscience, vol. 6, no. 12, pp. 1317-1322, 2003.

[15] T. Teubner, M. Adam and R. Riordan, The impact of computerized agents on immediate emotions, overall arousal and bidding behavior in electronic auctions, Journal of the Association of Information Systems, vol. 16, no. 10, pp. 838-879, 2015.

[16] Y. Tian and C. Stewart, History of e-commerce, in Electronic Commerce: Concepts, Methodologies, Tools, and Applications: Concepts, Methodologies, Tools, and Applications (A. Beker, Ed.). Hershey P.A., IGI Global, 2007, pp. 1-8.

[17] Z. Vladimir, Electronic commerce: Structures and issues, International Journal of Electronic Commerce, vol. 1, no. 1 , pp. 3-23, 1996.

[18] S. Xu, H. Jiang and F.C.M. Lau, Observing facial expressions and gaze positions for personalized webpage recommendation, in Proceedings ACM International Conference Proceeding Series, Proceedings of the 12th International Conference on Electronic Commerce: Roadmap for the Future of Electronic Business, Honolulu, HI, pp. 78-87, 2010.

[19] Z. Zhang and $\mathrm{H}$. Teo, Metacognition in B2C E-commerce: A cognitive neuroscience perspective, in Proceedings - Pacific Asia Conference on Information Systems, PACIS, Chengdu, China, pp. 285, 2014. 


\section{Appendix A: The Most Cited Papers ( $\geq 10$ citations)}

\begin{tabular}{|c|c|c|c|c|}
\hline & $\begin{array}{l}\text { Main } \\
\text { research } \\
\text { area }\end{array}$ & \# of citations & $\begin{array}{l}\text { Filed } \\
\text { Weight } \\
\text { Citation } \\
\text { Impact* }^{*}\end{array}$ & $\begin{array}{l}\text { Scopus } \\
\text { Percentile in } \\
\text { Main } \\
\text { Research } \\
\text { Area* }^{*}\end{array}$ \\
\hline $\begin{array}{l}\text { Cyr, D., Head, M., Larios, H., \& Pan, B. (2009). } \\
\text { Exploring human images in website design: a } \\
\text { multi-method approach. MIS quarterly, 539-566 }\end{array}$ & $\begin{array}{l}\text { Computer } \\
\text { sciences }\end{array}$ & 209 & 7,83 & $99 \%$ \\
\hline $\begin{array}{l}\text { Wang, Q., Yang, S., Liu, M., Cao, Z., \& Ma, Q. } \\
\text { (2014). An eye-tracking study of website } \\
\text { complexity from cognitive load } \\
\text { perspective. Decision support systems, } 62,1-10 .\end{array}$ & $\begin{array}{l}\text { Arts and } \\
\text { Humanities }\end{array}$ & 30 & 4,24 & $97 \%$ \\
\hline $\begin{array}{l}\text { Sivaji, A., Downe, A. G., Mazlan, M. F., Soo, S. T., } \\
\& \text { Abdullah, A. (2011). Importance of incorporating } \\
\text { fundamental usability with social \& trust elements } \\
\text { for e-commerce website. In Business, Engineering } \\
\text { and Industrial Applications (ICBEIA), 2011 } \\
\text { International Conference on (pp. 221-226). IEEE. }\end{array}$ & $\begin{array}{l}\text { Business, } \\
\text { Management } \\
\text { and } \\
\text { Accounting }\end{array}$ & 21 & 11,43 & $98 \%$ \\
\hline $\begin{array}{l}\text { Huang, Y. F., \& Kuo, F. Y. (2012). How impulsivity } \\
\text { affects consumer decision-making in e- } \\
\text { commerce. Electronic Commerce Research and } \\
\text { Applications, } 11(6), 582-590 .\end{array}$ & $\begin{array}{l}\text { Business, } \\
\text { Management } \\
\text { and } \\
\text { Accounting }\end{array}$ & 19 & 1,32 & $84 \%$ \\
\hline $\begin{array}{l}\text { Castagnos, S., Jones, N., \& Pu, P. (2010, } \\
\text { September). Eye-tracking product recommenders' } \\
\text { usage. In Proceedings of the fourth ACM } \\
\text { conference on Recommender systems (pp. 29-36). } \\
\text { ACM. }\end{array}$ & Engineering & 19 & 3,86 & $96 \%$ \\
\hline $\begin{array}{l}\text { Goh, K. N., Chen, Y. Y., Lai, F. W., Daud, S. C., } \\
\text { Sivaji, A., \& Soo, S. T. (2013, April). A comparison } \\
\text { of usability testing methods for an e-commerce } \\
\text { website: A case study on a Malaysia online gift } \\
\text { shop. In Information Technology: New Generations } \\
\text { (ITNG), 2013 Tenth International Conference } \\
\text { on (pp. 143-150). IEEE. }\end{array}$ & $\begin{array}{l}\text { Computer } \\
\text { sciences }\end{array}$ & 17 & 7,08 & $97 \%$ \\
\hline $\begin{array}{l}\text { Wook Chae, S., \& Chang Lee, K. (2013). Exploring } \\
\text { the effect of the human brand on consumers' } \\
\text { decision quality in online shopping: An eye- } \\
\text { tracking approach. Online Information } \\
\text { Review, } 37(1), 83-100 .\end{array}$ & Engineering & 14 & 1,58 & $70 \%$ \\
\hline $\begin{array}{l}\text { Schmutz, P., Roth, S. P., Seckler, M., \& Opwis, K. } \\
\text { (2010). Designing product listing pages-Effects on } \\
\text { sales and users' cognitive workload. International } \\
\text { journal of human-computer studies, 68(7), 423- } \\
431 .\end{array}$ & Engineering & 10 & 1,03 & $55 \%$ \\
\hline
\end{tabular}

Source: Author's work based on citation analysis

Note: * Corrected for the year of publication, document type and main research area; Field-Weighted Citation Impact greater than 1 indicates that the paper is cited more than expected in average 